\title{
OBSERVATORIO
}

\section{SOCIAL MEDIA AND DEMOCRACY}

\section{Medios sociales y democracia}

\author{
Homero Gil de Zúñiga, Brigitte Huber and Nadine Strauß
}

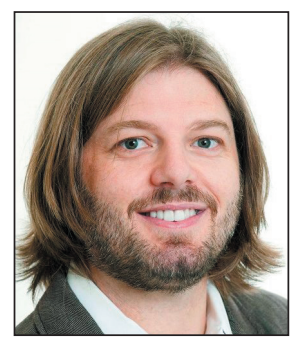

Homero Gil de Zúñiga, Ph.D. in Politics at Universidad Europea de Madrid and Ph.D. in Mass Communication at University of Wisconsin, Madison, holds the Medienwandel Professorship at University of Vienna, where he directs the Media Innovation Lab (MiLab). He also serves or has served as Research Fellow at Universidad Diego Portales, Chile, at the Center for Information Technology Policy at Princeton University, and the Nieman Journalism Lab at Harvard University. His research addresses the influence of new technologies and digital media over people's daily lives, as well as the effect of such use on the overall democratic process. He has produced over 250 books, book chapters, journal articles, and refereed conferences papers (i.e. Journal of communication, Communication research, Journal of computer-mediated communication, Human communication research, New media \& society, etc.).

https://orcid.org/0000-0002-4187-3604

University of Vienna, Department of Communication Althanstraße 14 (UZA II), Room 3.09, 1090 Vienna, Austria homero.gil.de.zuniga@univie.ac.at

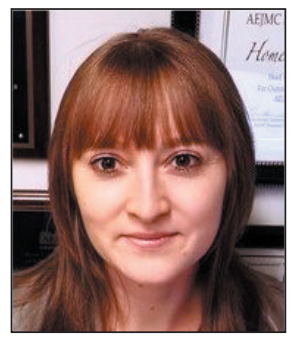

Brigitte Huber is a postdoc at the Media Innovation Lab of the Department of Communication at the University of Vienna. After finishing her Ph.D., she worked at the Department of Communication Science and Media Research at the Ludwig Maximilian University of Munich. Her research interests include political communication, social media, journalism studies, and science communication. Currently, her research addresses pro-social and pro-democratic effects of rising online communication practices such as second screening.

https://orcid.org/0000-0002-9070-4962

University of Vienna, Media Innovation Lab (MiLab) Althanstraße 14 (UZA II), 1090 Vienna, Austria brigitte.huber@univie.ac.at

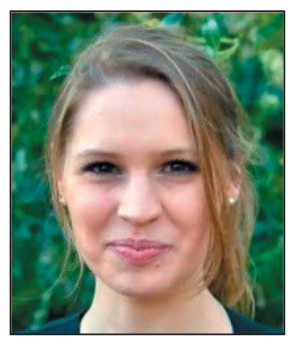

Nadine Strauß is a postdoc at the Media Innovation Lab of the Department of Communication at the University of Vienna. She obtained her Ph.D. from the Amsterdam School of Communication Research (ASCOR), University of Amsterdam. Her research interests include political communication, journalism studies, financial communication, and news use.

https://orcid.org/0000-0002-5050-7067

University of Vienna, Media Innovation Lab (MiLab) Althanstraße 14 (UZA II), 1090 Vienna, Austria nadine.strauss@univie.ac.at

\begin{abstract}
Slowly approaching the second quarter of the $21^{\text {st }}$ century, research on social media and its effects over democracy has quickly permeated across various fields in social sciences, particularly political communication. Based on accumulated evidence in this strand of literature, this paper briefly summarizes several established research areas. First, it highlights how social media facilitates individuals' political expression. Second, it sheds light on how this enhanced communicative behavior has reinvigorated a more participatory society in democracy. Third, it examines social media's democratic deficit mechanisms in regards to stagnant political knowledge acquisition. Finally, the paper offers a theoretical explanation to this lack of knowledge acquisition through the lenses of the 'news-finds-me' perception theory. Overall, the present manuscript explains specific ways in which social media helps and hinders the advancement of healthy democracies, thereby also providing promising guidelines for future research.
\end{abstract}




\section{Keywords}

Social media; Political expression; Political participation; Political knowledge; “News-finds-me” perception; NFM.

\section{Resumen}

Acercándonos ya al segundo cuarto del siglo XXI, la investigación en las redes sociales y sus efectos sobre la democracia ha permeado rápidamente en varios campos de las ciencias sociales, particularmente en la comunicación política. Basándonos en la evidencia acumulada en esta línea de bibliografía, este artículo resume brevemente varias áreas de investigación. Primero, destaca cómo los medios sociales facilitan la expresión política de los individuos. Segundo, arroja luz sobre cómo este comportamiento comunicativo mejorado ha revitalizado una sociedad más participativa en la democracia. En tercer lugar, examina los mecanismos de déficit democrático de las redes sociales en relación con la adquisición de conocimientos políticos. Finalmente, el artículo ofrece una explicación teórica a esa falta de adquisición de conocimiento a través de la teoría de la percepción "las noticias me encuentran". En general, el presente manuscrito explica formas específicas en que las redes sociales ayudan u obstaculizan el avance de democracias saludables, proporcionando así pautas prometedoras para futuras investigaciones.

\section{Palabras clave}

Medios de comunicación social; Redes sociales; Expresión política; Participación política; Conocimiento político; Percepción "las noticias me encuentran".

Gil de Zúñiga, Homero; Huber, Brigitte; Strauß, Nadine (2018). "Social media and democracy". El profesional de la información, v. 27, n. 6, pp. 1172-1180.

$\longrightarrow$ https://orcid.org/10.3145/epi.2018.nov.01

\section{Social media and democracy}

Research on social media has flourished in the past 15 years

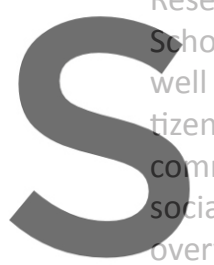
holars have been interested ell as negative effects that ens' daily life, as well as far s mmunication in particular ial media on political and civic participation (see for a this area of research and elaborates on three major conwith others to express their political views. But why is political expression so important? And why it is so unique in
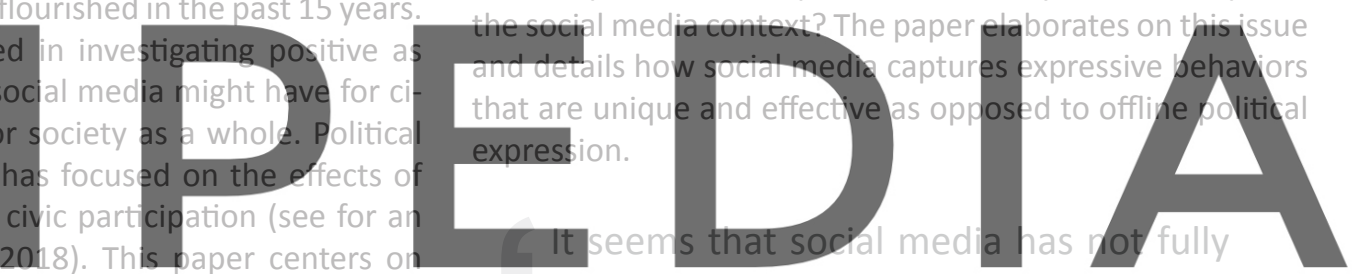

democracy. These are, among others,

- political expression,

- political participation, and

- political learning.

\section{Social media provides citizens with} opportunities to express themselves and openly share their ideas, opinions and viewpoints

First, by connecting people across the world, social media provides citizens with opportunities to express themselves and openly share their ideas, opinions and viewpoints. In doing so, it allows information to get rapidly disseminated afar. Various platforms, networks and tools offer citizens a plentitude of ways to share information that is meaningful to them, ignoring social, cultural or geographical borders. Expression should be understood as 'standalone communicative action', independent from a discussion, for instance, as individuals may share their thoughts with low or no expectation of social engagement at all. They just want the world to know how they feel, and what they think. As such, one specific form of expression is sharing their thoughts

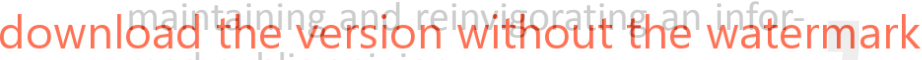 med public opinion}

Second, the paper discusses how political expression can become a powerful antecedent of political engagement. Social media has changed the norms of participation as well as the ways in which citizens become engage with politics (i.e., logic of networked action, less institutionalized politics as opposed to more individual network action, based on citizens). In short, the paper seeks to explain under what conditions social media might facilitate these participatory political processes.

Third, the paper discusses whether or not a more participatory society, in part due to social media, equates with a more informed participatory society. That is a pending question and research in this area is still in its infancy. So far, it seems that social media has not fully fulfilled its potential when it comes to maintaining and reinvigorating an informed public opinion. In the light of this discussion, there are two opposing views,

a) social media helps people to acquire necessary information, leading to political mobilization, or conversely,

b) social media does not fulfill this political knowledge task, leading people to participate without deep political issues knowledge gain. 
The paper offers a theoretical account to clarify the mechanisms between social media use and political learning, or a lack thereof: The "news-finds-me perception" (NFM).

\section{Social media and political expression}

Social media has the potential to foster democracy in various ways. One way is helping citizens to get exposed to news, either actively or incidentally, which has found to be positively related to political participation (Saldaña; McGregor; Gil de Zúñiga, 2015; Kim; Chen; Wang, 2016). Furthermore, it has been argued that social media can facilitate political expression, a crucial alley for people to get engaged in politics (Pingree, 2007). But how does social media facilitate political expression exactly? First, the interactive feature of social media enables people to share ideas with many people simultaneously. That is, the expressive potential of people has changed as they are able to

"post, at minimal cost, messages and images that can be viewed instantly by global audiences" (Lupia; Sin, 2003, p. 316).

Second, social media allows people to get in touch with a wide range of different people. Research has shown that people tend to express themselves more where networks are more heterogenous (Barnidge; Huber; Gil de Zúñiga; Liu, 2018).

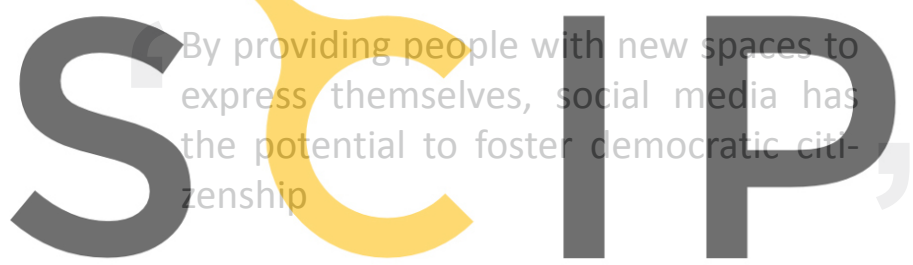

Third, social media as a user-friendly platform cultivates

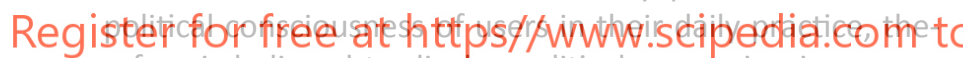
refore is believed to display political expression in a more accessible format and spirited condition, ultimately facilitating expression and participation (Gil-de-Zúñiga; Molyneux; Zheng, 2014).

There is an array of possibilities of how people can express themselves on social media -ranging from live-tweeting on content watched on TV (see "second screening" or "dual screening"; Chadwick; O’Loughlin; Vaccari, 2017; Gil-deZúñiga; García-Perdomo; McGregor, 2015; Gil de Zúñiga; Liu, 2017; McGregor; Mourão, 2017) to liking/following political actors (Tromble, 2018; Sørensen, 2016; Vaccari; Valeriani, 2015). Also, people's motivations to express themselves on social media are manifold. While for some people it is a way to represent social identity (Correa; Jeong, 2011; Papacharissi, 2011), others want to take "corrective actions" (Rojas, 2010) of potential biases in the public sphere, or are driven by the wish to persuade others (Thorson, 2014; Kwak et al., 2018). Whichever the case, by providing people with new spaces to express themselves, social media has the potential to foster democratic citizenship (Yu; Oh, 2018). For example, having more opportunities for expressing themselves may help mobilize people to take real-world actions (Elin, 2003). Indeed, political expression on Facebook was found to facilitate the process of engaging in political pro- tests (Chan, 2016). In the following, we elaborate on this and further ways in which social media promotes political participation.

\section{Social media and political participation}

Numerous studies have established a positive link between digital media use and political participation (for an overview, see Boulianne, 2015; 2018). Yet, how does social media promote political participation? As elaborated above, political expression is an important antecedent of political participation.

"Political expression is conceptually distinct from political participation in the way that political talk is distinct from political action" (Gil de Zúñiga et al., 2010).

Research shows that political talk precedes political action (Huckfeldt; Sprague, 1995). Similarly, political expression might work to enable political action by causing the expresser to alter his self-percention (Bem, 1967) from observer to participant. Pingree (2007) argues that expression may be the first step toward better citizenship by motivating

"exposure, attention and elaboration of media messages" (Pingree, 2007, p. 447).

Interestingly, positive effects of political expression already start in the preparation process of the expression: When individuals compose messages in their minds, information
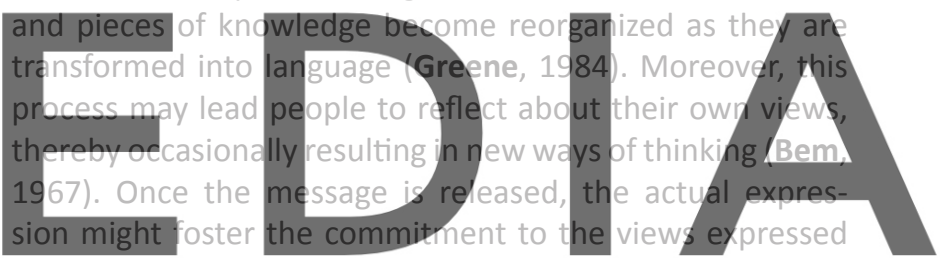

(Tetlock; Skitka; Boettger, 1989; Yoo; Kim; Gil de Zúñiga, 2017) and create the feeling that the speaker's voice has

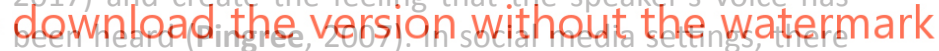

is always an audience for whom messages can be composed and to whom they may easily be released (Kim; Chadha; Gil de Zúñiga, 2018). Hence, social media may facilitate the process of political expression by providing a convenient platform including audience for it. And not only that, social media often is also the source of information needed to compose messages: Research shows a positive relationship between using social media to get news about politics and public affairs and political expression on social media (Gil de Zúñiga; Molyneux; Zheng, 2014). One common way of encountering information about public affairs and politics on social media platform is by getting incidentally exposed to news (see last section of the manuscript). This also entails the chance to get exposed to mobilizing information (Segesten; Bossetta, 2017). As social media tend to expand social networks (Kim et al., 2013a), this attribute might enhance the likelihood to come across information that motivates individuals to engage in politics. A plentitude of studies have shown that social media has the potential to foster several forms of political activities online (i.e., to create an online petition, make a campaign contribution, sign up to volunteer for a political campaign, etc.) as well as in real-life (i.e., attend a political rally, boycott a certain product or service because of the social or political values of the company, par- 
ticipate in any demonstrations, protests, or marches, etc.) (see for example, Park; Kaye, 2018; Gil de Zúñiga; Molyneux; Zheng, 2014). Hence, the potential of social media to foster political engagement is not limited to the digital environment but clearly, also has impacts in offline settings (see also de De-Aguilera; Casero-Ripollés, 2018).

Social media has the potential to foster several forms of political activities online as well as in real-life

\section{Social media and political learning}

Besides the positive effects for democracy highlighted above, social media can also be a cause for concern when it comes to political learning. While initially, optimists were full of hope that digital media could lead to an enhanced informed citizenry, recent findings suggest the opposite. In "Is Facebook making us dumber?". Cacciatore and colleagues (2018) have given an initial answer to this question by showing that using Facebook for consuming and sharing news is negatively related to political knowledge. However, there is also reasons for hope. Bode's (2016) results from an experimental study have shown that individuals who get exposed to political information via social media have learned from it.

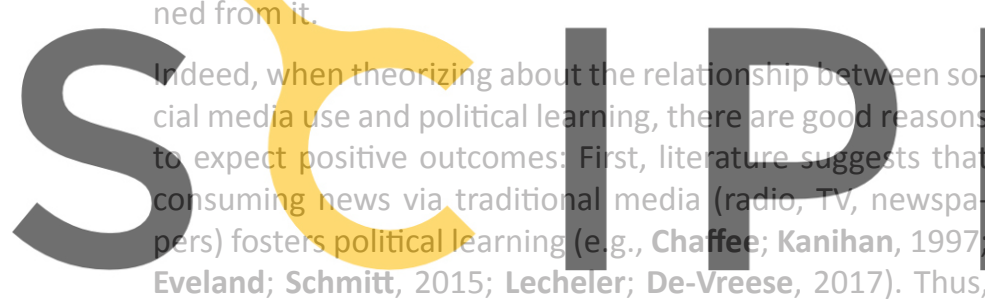
consuming news on social media sites could do so as well.

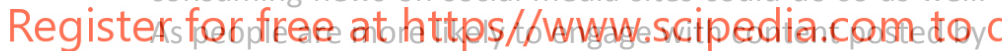
people they feel alike (Bonchi; Castillo; Ienco, 2013; Ma; Lee; Goh, 2013) and closer to (Ganley; Lempe, 2009; Wang; Mark, 2013), people might benefit from consuming news shared by peers on social media. Second, the fact that people often get incidentally exposed to news might also be beneficial for learning processes, as this was found to increase the use of further online news sources (Fletcher; Nielsen, 2018).

However, social media may not become a positive conduit to political learning. In fact, it has been argued that, news choices and individual characteristics (i.e. prior education levels, political interest, etc.) could generate gaps in knowledge within the context of social media (Prior, 2007). For example, questions arise whether or not social media provide per se the type of news necessary for individuals to learn, and different types of social media platforms may also generate diverse effects (Yoo; Gil-de-Zúñiga, 2014). Research shows that relative to a number of other news topics, news about politics is shared at a much lower level on social media (Bright, 2016). Over time, this may create what Bright calls a 'social news gap' in which people who consume news on social media hold different perceptions of the news agenda than traditional news users, which may in turn lead social media news users to become disinterested and disengaged with political news altogether (Bright, 2016). If so, social media could create the same preference- and individual-based knowledge disparities outlined by Prior (2007). Moreover, when people see news in social media but do not click on it, consume it, or process it, the simple exposure may not be enough for passive learning, as it is the case with television (Shehata, 2013). Although people can recall political information from social media (Bode, 2016), social media use generally may not be linked to greater political knowledge gain (Dimitrova et al., 2014), or only enhances learning for highly educated individuals (Yoo; Gil de Zúñiga, 2014). Despite the affluence of news and information in social media, active learning might become a prerequisite for political learning to unfold on this platform. One theoretical account that helps to better understand this phenomenon is the so called "news-finds-me perception (NFMP)".

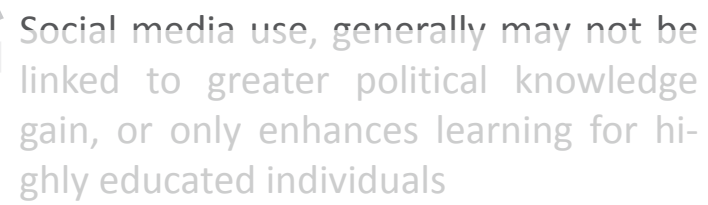

\section{The news-finds-me perception theory}

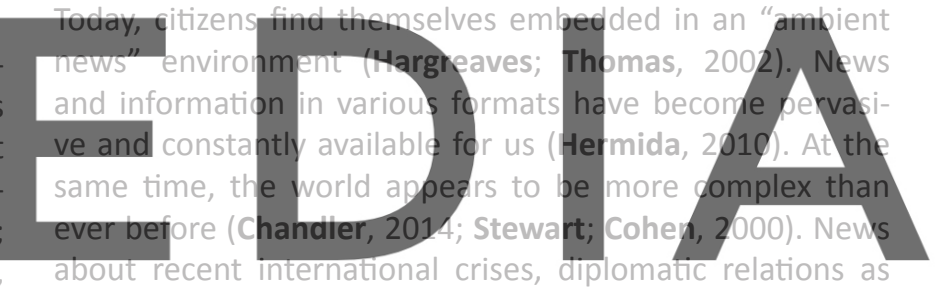
well as the opaque and dubious intervention of internatio-

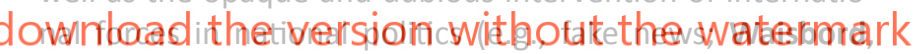
2018) present citizens with a constant flow of seemingly unsolvable issues the world is facing. While for some citizens this fast-pace news cycle simply presents a challenge to keep up with, others tend to get tired of the news (e.g., news fatigue: Nordensen, 2008) or ignore them completely (Trilling; Schöenbach, 2012). Yet, coupled with a change in media technologies, others might perceive the "ambient" news environment advantageous in order to stay abreast of news. Various online or hybrid media channels, social media platforms or conversations online have facilitated ways to stay informed about current issues and politics nowadays (Fletcher; Nielsen, 2018). Recent figures of increased news consumption via social media channels worldwide support this assumption (Newman et al., 2017; 2018).

Furthermore, with the emergence of news broadcasting on social media channels and other online platforms, the notion of "incidental news exposure" has emerged. That is, individuals become exposed to news and information about politics and public affairs on social media channels and while browsing through the Net, although not actively seeking it (Fletcher; Nielsen, 2018; Hermida, 2010; Kim et al., 2013b; Mitchell et al., 2016). The benefits of incidental news exposure for political knowledge or knowledge about issues discussed in the news are, however, contested. While one 
stream of research has found that being incidentally exposed to news on social media supports the learning of political facts (Bode, 2016; Shehata et al., 2015), another stream has shown that incidental news exposure is not necessarily beneficial for knowledge gains (Müller; Schneiders; Schäfer, 2016; Oeldorf-Hirsch, 2018). One important distinction one has to make when studying learning processes based on news consumption is whether citizens actually believe they are well informed while browsing through the net, or whether they still believe they have to actively seek the news despite being incidentally exposed to news. This difference might explain why some might learn from incidental news exposure, and others not. Researchers have identified this belief as the "news-finds-me" (NFM) perception (Gil de Zúñiga; Weeks; Ardèvol-Abreu, 2017).

While for some citizens this fast-pace news cycle simply presents a challenge to keep up with, others tend to get tired of the news

The NFM perception is conceptualized based on three dimensions. First, it describes the perception that one is weIl-informed without purposely following the news and, second, that important information will "find one" anyways

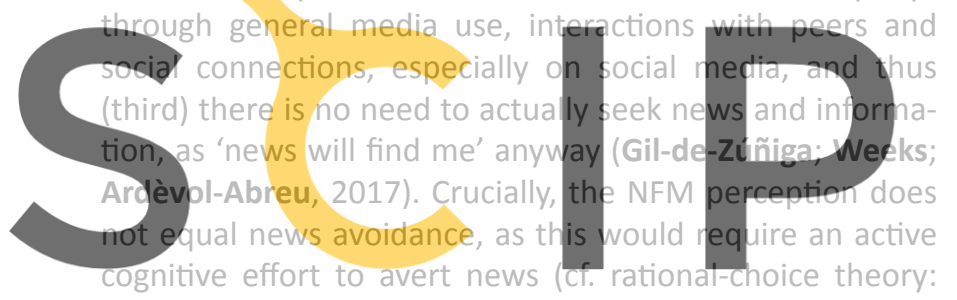
Doyle, 1999). Similarly, it does not resemble a disinterest in

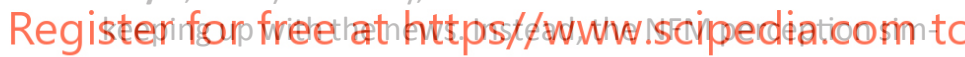
ply implies the belief to stay informed about recent news through other channels than official news sources (e.g., being active on social media, participating in online conversations, or browsing through the Net). However, while the NFM perception does not exclude incidental news exposure, and thus potential learning benefits, recent studies that have investigated the consequences of the NFM perception give reasons for concern.

The NFM describes the perception that one is well-informed without purposely following the news and, that important information will "find one" anyway

To begin with, findings from a survey study among US citizens have shown that the NFM perception is associated with a strong reliance on social media for news consumption. Traditional news outlets such as print news or television news, on the other hand, are negatively related with the NFM perception (Gil de Zúñiga; Weeks; Ardèvol-Abreu, 2017). While it has been argued that news consumption via traditional news might be more beneficial for democratic processes (e.g., offline political participation) than news consumption via social media, if not explicitly politically motivated (Holt et al., 2013), the proliferation of the NFM perception among citizens around the world becomes distressing in light of a well-informed citizenry. In fact, another survey study with a representative sample in the US has shown that while there is no direct relationship between the NFM perception and voting behavior, there are robust and direct negative associations between the NFM perception and both political knowledge and political interest (Gil de Zúñiga; Diehl, in press). In addition, a negative mediating effect of the NFM perception through political interest and political knowledge on voting behavior could be identified. These finding give reasons to believe that the NFM perception presents a danger for thriving democratic societies in which citizens are politically interested, actively inform themselves about politics and public affairs, develop a basic understanding of politics and current issues, and take part in democratic processes (e.g., voting).

\section{Citizens might have developed the false belief to be well-informed without acti- vely following the news (cf. NFM percep- tion)}

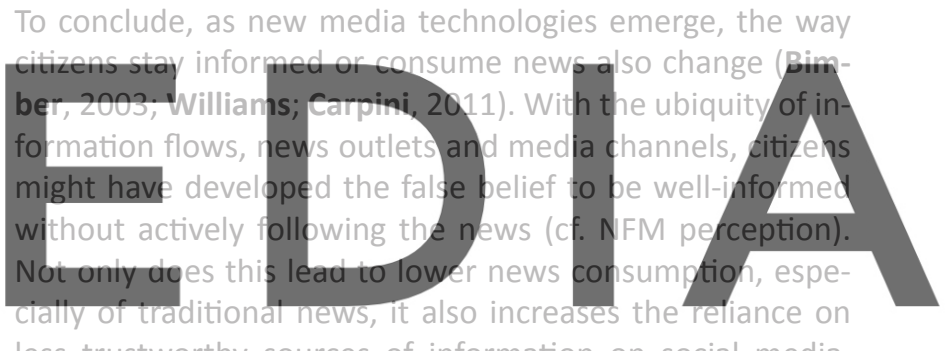

less trustworthy sources of information on social media.

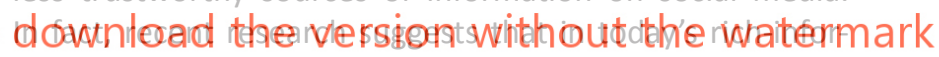
mation environment, the role of interest in the news has become an even more decisive factor for citizens and their news seeking behavior (Hopmann et al., 2016; Strömbäck; Djerf-Pierre; Shehata, 2013). In a similar vein, new media technologies have not been proven to be a guarantee to fuel political interest and political engagement (Bimber et al., 2015). Instead, the "new" news environment and the reliance on one's own social networks for news and information can be considered detrimental for democratic behavior (e.g., interest) and processes (e.g., voting). Furthermore, the strong reliance on personal networks for news consumption might be nucleus for fostering 'filter bubbles' (Pariser, 2011) and 'information cocoons' (Sunstein, 2018) that are characterized by homogenous political opinions and viewpoints. Instead of seeking out a diverse set of news sources and information, citizens become highly dependent on what is shown and presented to them within their social networks, which are furthermore colonized by fake news and in command of algorithms, controlled by a few, influential technological conglomerates.

All in all, this paper highlighted specific mechanisms by which social media facilitates more robust and participatory democracies. In parallel, the manuscript also theorized the ways in which social media will not serve as a positive con- 
duit to political learning, particularly via the proliferation of the NFM perception. Future research, however, needs to further and systematically delve into these issues to continue to move forward a programmatic agenda on social media and democracy.

The strong reliance on personal networks for news consumption might be nucleus for fostering 'filter bubbles' and 'information cocoons' that are characterized by homogenous political opinions and viewpoints

\section{References}

Barnidge, Matthew; Huber, Brigitte; Gil de Zúñiga, Homero; Liu, James H. (2018). "Social media as a sphere for 'risky' political expression: A 20-country multi-level comparative analysis". International journal of press \& politics, v. 23, n. 2, pp. 161-182. https://doi.org/10.1177/1940161218773838

Bem, Daryl J. (1967). "Self-perception: An alternative interpretation of cognitive dissonance phenomena". Psychological review, v. 74, n. 3, pp. 183-200.

https://goo.gl/1sQvYx

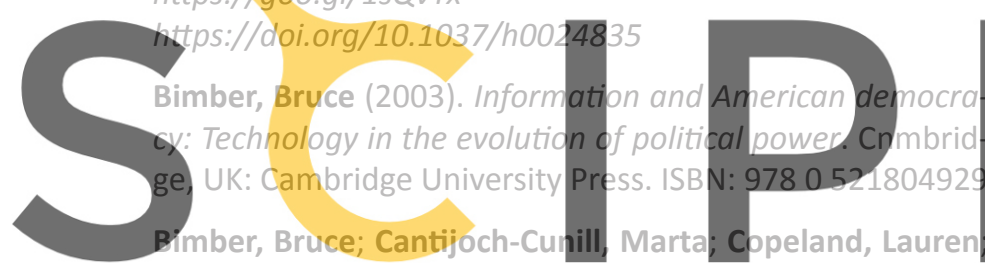

Gibson, Rachel (2015). "Digital media and political participation: The moderating role of political interest across acts

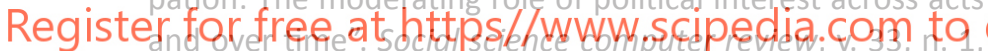
pp. 21-42.

https://www.dhi.ac.uk/san/waysofbeing/data/citizenship robson-bimber-2015.pdf

https://doi.org/10.1177/0894439314526559

Bode, Leticia (2016). "Political news in the news feed: Learning politics from social media". Mass communication and society, v. 19 , pp. 24-48.

https://doi.org/10.1080/15205436.2015.1045149

Bonchi, Francesco; Castillo, Carlos; lenco, Dino (2013). "Meme ranking to maximize post vitality in microblogging platforms". Journal of intelligent information systems, v. 40, n. 2, pp. 211-231.

https://doi.org/10.1007/s10844-011-0181-4

Boulianne, Shelley (2015). "Social media use and participation: A meta-analyis of current research". Information, communication \& society, v. 18, n. 5, pp. 524-538.

https://doi.org/10.1080/1369118X.2015.1008542

Boulianne, Shelley (2018). "Twenty years of digital media effects on civic and political participation". Communication research, pp. 1-20 (online first). https://doi.org/10.1177/0093650218808186

Bright, Jonathan (2016). "The social news gap: How news reading and news sharing diverge". Journal of communication, v. 66, n. 3, pp. 343-365.

https://doi.org/10.1111/jcom.12232

Cacciatore, Michael A.; Yeo, Sara K.; Scheufele, Dietram A.; Xenos, Michael A.; Brossard, Dominique; Corley, Elizabeth A. (2018). "Is Facebook making us dumber? Exploring social media use as a predictor of political knowledge". Journalism \& mass communication quarterly, v. 95, n. 2, pp. 404-424. https://doi.org/10.1177/1077699018770447

Chadwick, Andrew; O'Loughlin, Ben; Vaccari, Cristian (2017). "Why people dual screen political debates and why it matters for democratic engagement". Journal of broadcasting \& electronic media, v. 61, n. 2, pp. 220-239. https://doi.org/10.1080/08838151.2017.1309415

Chaffee, Steven H.; Kanihan, Stacey F. (1997). "Learning about politics from the mass media". Political communication, v. 14, n. 4, pp. 421-430.

https://doi.org/10.1080/105846097199218

Chan, Michael (2016). "Social network sites and political engagement: Exploring the impact of Facebook connections and uses on political protest and participation". Mass communication and society, v. 19, n. 4, pp. 430-451. https://doi.org/10.1080/15205436.2016.1161803

Chandller, David (2014). Resilience: The governance of com-

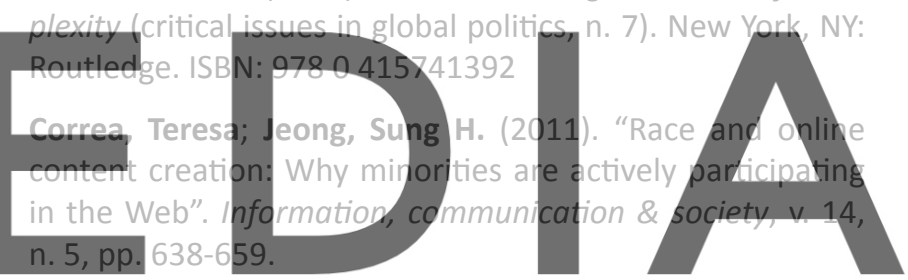

https://doi.org/10.1080/1369118X.2010.514355

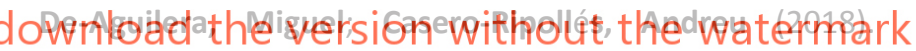
"¿Tecnologías para la transformación? Los medios sociales ante el cambio político y social". Icono14, v. 16, n. 1, pp. $1-21$.

https://doi.org/10.7195/ri14.v16i1.1162

Dimitrova, Daniela V.; Shehata, Adam; Strömbäck, Jesper; Nord, Lars W. (2014). "The effects of digital media on political knowledge and participation in election campaigns: Evidence from panel data". Communication research, v. 41, n. 1 , pp. 95-118.

https://doi.org/10.1177/0093650211426004

Doyle, Jon (1999). "Rational decision making". In: Wilson, Robert A.; F. Keil, Frank C. (eds.). The MIT encyclopedia of the cognitive sciences. Cambridge, MA: MIT Press, pp. 701703. ISBN $026273124 \mathrm{X}$

http://www.aiai.ed.ac.uk/project/oplan/documents/1999/1999MITECS.pdf

Elin, Larry (2003). "The radicalization of Zeke Spier: How the Internet contributes to civic engagement and new forms of social capital". In: McCarthy, Martha; Ayers, Michael D. (eds.). Cyberactivism: Online activism in theory and practice. New York, NY: Routledge, pp. 97-116. ISBN: 0415943191

Eveland, William P.; Schmitt, Josephine B. (2015). "Communication content and knowledge content matters: Inte- 
grating manipulation and observation in studying news and discussion learning effects". Journal of communication, v. 65 , n. 1, pp. 170-191.

https://doi.org/10.1111/jcom.12138

Fletcher, Richard; Nielsen, Rasmus-Kleis (2018). "Are people incidentally exposed to news on social media? A comparative analysis". New media \& society, v. 20, n. 7, pp. 2450 2468.

https://doi.org/10.1177/1461444817724170

Ganley, Dale; Lampe, Cliff (2009). "The ties that bind: Social network principles in online communities". Decision support systems, v. 47, n. 3, pp. 266-274.

https://doi.org/10.1016/j.dss.2009.02.013

Gil de Zúñiga, Homero; Diehl, Trevor (in press). "News finds me perception and democracy: Effects on political knowledge, political interest, and voting". New media \& society. https://journals.sagepub.com/home/nmsa

Gil de Zúñiga, Homero; García-Perdomo, Víctor; McGregor, Shannon (2015). "What is second screening? Exploring motivations of second screen use and its effects on online political participation". Journal of communication, v. 65, n. 5, pp. 793-815.

https://doi.org/10.1111/jcom.12174

Gil de Zúñiga, Homero; Liu, James H. (2017). "Second scree-

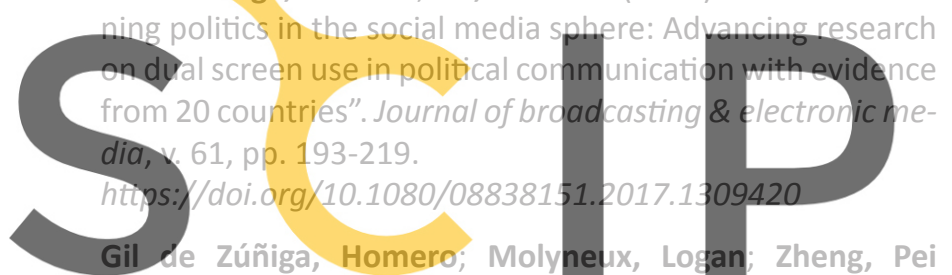

(2014). "Social media, political expression, and political participation: Panel analysis of lagged and concurrent relations

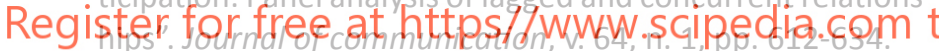
https://doi.org/10.1111/jcom.12103

Gil de Zúñiga, Homero; Veenstra, Aaron; Vraga, Emily; Shah, Dhavan (2010). "Digital democracy: Re-imagining pathways to political participation". Journal of information technology \& politics, v. 7, n. 1, pp. 36-51.

https://doi.org/10.1080/19331680903316742

Gil de Zúñiga, Homero; Weeks, Brian; Ardèvol-Abreu, Alberto (2017). "Effects of the news-finds-me perception in communication: Social media use implications for news seeking and learning about politics". Journal of computer-mediated communication, v. 22, n. 3, pp. 1-19.

https://doi.org/10.1111/jcc4.12185

Greene, John O. (1984). "A cognitive approach to human communication: An action assembly theory". Communication monographs, v. 51, n. 4, pp. 289-306. https://doi.org/10.1080/03637758409390203

Hargreaves, Ian; Thomas, James (2002). New news, old news. London: Independent Television Commission/Broadcasting Standards Commission. ISBN: 9780900485992

Hermida, Alfred (2010). "Twittering the news: The emergence of ambient journalism". Journalism practice, v. 4, n. 3, pp. 297-308. https://doi.org/10.1080/17512781003640703

Holt, Kristoffer; Shehata, Adam; Strömbäck, Jesper; Ljungberg, Elisabet (2013). "Age and the effects of news media attention and social media use on political interest and participation: Do social media function as leveller?". European journal of communication, v. 28, n. 1, pp. 19-34.

https://doi.org/10.1177/0267323112465369

Hopmann, David-Nicholas; Wonneberger, Anke; Shehata, Adam; Höijer, Jonas (2016). "Selective media exposure and increasing knowledge gaps in Swiss referendum campaigns". International journal of public opinion research, v. 28, n. 1, pp. 73-95.

https://doi.org/10.1093/ijpor/edv002

Huckfeldt, Robert R.; Sprague, John (1995). Citizens, politics, and social communication: Information and influence in an election campaign. New York, NY, US: Cambridge University Press. ISBN: 9780511664113

https://doi.org/10.1017/CB09780511664113

Kim, Ji-Won; Chadha, Monica; Gil de Zúñiga, Homero (2018). "News media use and cognitive elaboration: The mediating role of media efficacy". Revista latina de comunicación social, v. 73, pp. 168-183.

https://doi.org/10.4185/RLCS-2018-1251en

Kim, Yonghwan; Chen, Hsuan-Ting; Wang, Yuan (2016). "Living in the smartphone age: Examining the conditional indi-
rect effects of mobile phone use on political participation"
Journal of broadcasting \& electronic media, v. 60, n/4, pp.
$694-713$.
https://doi.org/10.1080/0883\$151.2016.1203318
Kim, Yonghwan; Chen, Hsuan- ting; Gil de Zúñiga, Homero
(2013a). "Stumbling upon news on the internet: Effect of incidental news exposure and relative entertainment use on

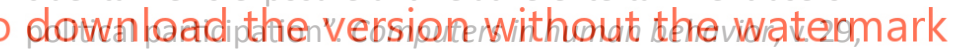
n. 6, pp. 2607-2614

https://doi.org/10.1016/j.chb.2013.06.005

Kim, Yonghwan; Hsu, Shih-Hsien; Gil de Zúñiga, Homero (2013b). "Influence of social media use on discussion network heterogeneity and civic engagement: The moderating role of personality traits". Journal of communication, v. 63, n. 3, pp. 498-516.

https://doi.org/10.1111/jcom.12034

Kwak, Nojin; Lane, Daniel S.; Lee, Sigi S.; Liang, Fan; Weeks, Brian E. (2018). "From persuasion to deliberation: Do experiences of online political persuasion facilitate dialogic openness?". Communication research, pp. 1-23 (online first).

https://doi.org/10.1177/0093650218793050

Lecheler, Sophie; De-Vreese, Claes H. (2017). “News media, knowledge, and political interest: Evidence of a dual role from a field experiment". Journal of communication, v. 67, n. 4, pp. 545-564.

https://doi.org/10.1111/jcom.12314

Lupia, Arthur; Sin, Gisela (2003). "Which public goods are endangered? How evolving communication technologies affect The logic of collective action". Public choice, n. 117, pp. 315-331. 
https://goo.gl/yPcVmN

Ma, Long; Lee, Chei-Sian; Goh, Dion H. (2013). “Understanding news sharing in social media from the diffusion of innovations perspective". In: IEEE Int/ conf on cyber, physical, and social computing. New York: IEEE.

https://doi.org/10.1109/GreenCom-iThings-CPSCom.2013.173

McGregor, Shannon C.; Mourão, Rachel R. (2017) "Second screening Donald Trump: Conditional indirect effects on political participation". Journal of broadcasting \& electronic media, v. 61, n. 2, pp. 264-290.

https://doi.org/10.1080/08838151.2017.1309418

Mitchell, Amy; Gottfried, Jeffrey; Barthel, Michael; Shearer, Elisa (2016). The modern news consumer. News attitudes and practices in the digital era. Pew Research Center. http://www.journalism.org/2016/07/07/the-modern-newsconsumer

Müller, Philipp; Schneiders, Pascal; Schäfer, Svenja (2016). "Appetizer or main dish? Explaining the use of Facebook news posts as a substitute for other news sources". Computers in human behavior, v. 65, pp. 431-441.

https://doi.org/10.1016/j.chb.2016.09.003

Newman, Nic; Fletcher, Richard; Kalogeropoulos, Antonis Levy, David A. L.; Nielsen, Rasmus K. (2017). Reuters Institute. Digital news report 2017

https://reutersinstitute.politics.

Digital\%20News\%20Report\%

Newman, Nic; Fletcher, Richard;

vy, David A. L.; Nielsen, Rasn

Digital news report 2018

p://media.digitalnewsreport.org/wp-content

uploads/2018/06/digital-news-report-2018.pdf?x89475

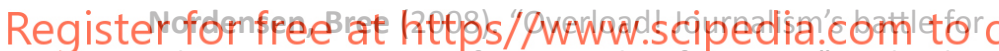
relevance in an age of too much information". Columbia journalism review.

http://www.uvm.edu/ jbrown7/envjournalism/overload.cjr.pdf

Oeldorf-Hirsch, Anne (2018). "The role of engagement in learning from active and incidental news exposure on social media". Mass communication and society, v. 21, n. 2, pp. 225-247.

https://doi.org/10.1080/15205436.2017.1384022

Papacharissi, Zizi (ed.) (2011). A networked self: Identity, community, and culture on social network sites. New York: Routledge, pp. 304-328. ISBN: 9780415801812

Pariser, Eli (2011). The filter bubble: What the Internet is hiding from you. New York, NY: Penguin. ISBN: 9780241954522

Park, Chang-Sup; Kaye, Barbara K. (2018). "News engagement on social media and democratic citizenship: Direct and moderating roles of curatorial news use in political involvement". Journalism \& mass communication quarterly, v. 95, n. 4, pp. 1103-1127.

https://doi.org/10.1177/1077699017753149

Pingree, Raymond J. (2007). "How messages affect their senders: A more general model of message effects and implications for deliberation". Communication theory, v. 17, n. 4, pp. 439-461. https://doi.org/10.1111/j.1468-2885.2007.00306.x

Prior, Markus (2007). Post-broadcast democracy: How media choice increases inequality in political involvement and polarizes elections. Cambridge, UK: Cambridge University Press. ISBN: 9780521675338

Rojas, Hernando (2010). "'Corrective' actions in the public sphere: How perceptions of media and media effects shape political behaviors". International journal of public opinion research, v. 22, n. 3, pp. 343-363.

https://doi.org/10.1093/ijpor/edq018

Saldaña, Magdalena; McGregor, Shannon; Gil de Zúñiga, Homero (2015). "Social media as a public space for politics: Cross-national comparison of news consumption and participatory behaviors in the United States and the United Kingdom". International journal of communication, v. 9, pp. 3304-3326.

https://ijoc.org/index.php/ijoc/article/view/3238

Segesten, Anamaria D.; Bossetta, Michael (2017). "A typology of political participation online: How citizens used Twitter to mobilize during the 2015 British general elections". Information, communication \& society, v. 20, n. 11, pp. 1625-1643

https://doi.org/10.1080/1369118X.2016.1252413

Shehata, Adam (2013). "Active or passive learning from te-

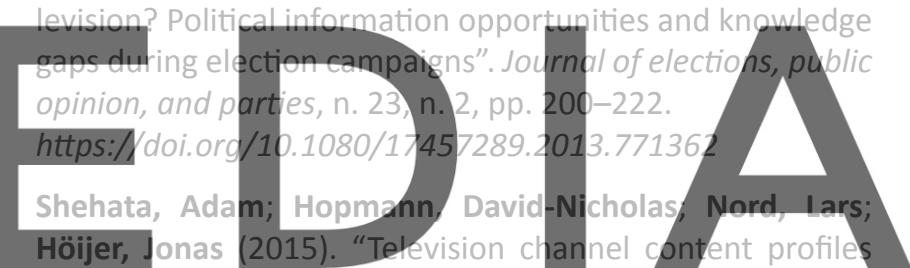

and differential knowledge growth: A test of the inadvertent learning hypothesis using panel, data". Political communicalownloganthe versigh without the watermark https://doi.org/10.1080/10584609.2014.955223

Sørensen, Mads P. (2016). "Political conversations on Facebook - the participation of politicians and citizens". Media, culture \& society, v. 38, n. 5, pp. 664-685.

https://doi.org/10.1177/0163443715620924

Stewart, Ian; Cohen, Jack (2000). The collapse of chaos: Discovering simplicity in a complex world. London, UK: Penguin. ISBN: 9780140291254

Strömbäck, Jesper; Djerf-Pierre, Monika; Shehata, Adam (2013). "The dynamics of political interest and news media consumption: A longitudinal perspective". International journal of public opinion research, v. 25, n. 4, pp. 414-435. https://doi.org/10.1093/ijpor/eds018

Sunstein, Cass (2018). \#Republic: Divided democracy in the age of social media. Princeton, NJ: Princeton University Press. ISBN: 9781400884711

Tetlock, Philip E.; Skitka, Linda; Boettger, Richard (1989). "Social and cognitive strategies for coping with accountability: Conformity, complexity, and bolstering". Journal of personality and social psychology, v. 57, n. 4, pp. 632-640.

Thorson, Emily (2014). "Beyond opinion leaders: How attempts to persuade foster political awareness and campaign 
learning". Communication research, v. 41, n. 3, pp. 353-374. https://doi.org/10.1177/0093650212443824

Trilling, Damian; Schöenbach, Klaus (2012). "Skipping current affairs: The non-users of online and offline news". European journal of communication, v. 28, n. 1, pp. 35-51. https://doi.org/10.1177/0267323112453671

Tromble, Rebekah (2018). "Thanks for (actually) responding! How citizen demand shapes politicians' interactive practices on Twitter". New media \& society, v. 20, n. 2, pp. 676-697. https://doi.org/10.1177/1461444816669158

Vaccari, Cristian; Valeriani, Augusto (2015). "Follow the leader! Direct and indirect flows of political communication during the 2013 Italian general election campaign". New media \& society, v. 17, n. 7, pp. 1025-1042.

https://doi.org/10.1177/1461444813511038

Waisbord, Silvio (2018). "Truth is what happens to news. On journalism, fake news, and post-truth". Journalism studies, v. 19, n. 13, pp. 1866-1878.

https://doi.org/10.1080/1461670X.2018.1492881

Wang, Yiran; Mark, Gloria (2013). "Trust in online news: Comprising social media and official media use by Chinese citizens". In: CSCQ'13. San Antonio, TX: ACM. https://doi.org/10.1145/2441776.2441843

Williams, Bruce A.; Carpini, Michael X. Delli (2011). After broadcast news: Media regimes, democracy, and the new information environment. New York, NY: Cambridge University Press. ISBN: 9780521279833

Yoo, Sung-Woo; Gil de Zúñiga, Homero (2014). “Connecting blog, Twitter and Facebook use with gaps in knowledge and participation". Communication \& society, v. 27, n. 4, pp. 3348.

https://doi.org/10.15581/003.27.4.33-48

Yoo, Sung-Woo; Kim, Ji-Won; Gil de Zúñiga, Homero (2017). "Cognitive benefits for senders: Antecedents and effects of political expression on social media". Journalism \& mass communication quarterly, v. 94, n. 1, pp. 17-37. https://doi.org/10.1177/1077699016654438

Yu, Rebecca-Ping; Oh, Yu-Won (2018). "Social media and expressive citizenship: Understanding the relationship between social and entertainment expression on Facebook and political participation". Telematics \& informatics, v. 35, n. 8, pp. 2299-2311

https://doi.org/10.1016/j.tele.2018.09.010
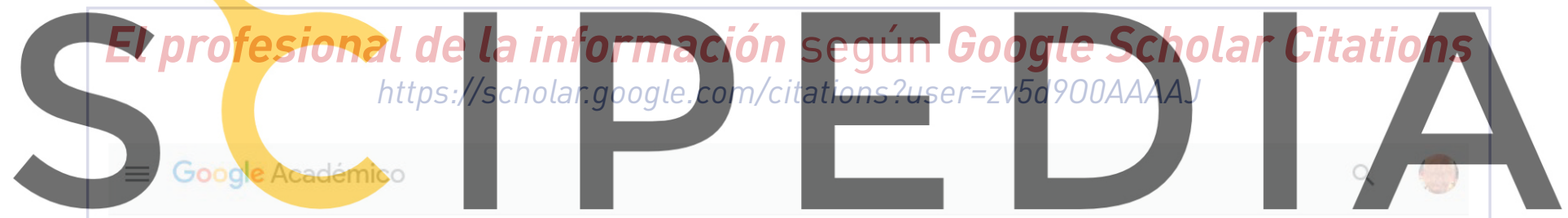

El profesional de la información

Register for free at httpsh/WwWW.Scipedia.com to download the version without the watermark

- (información- Dirección de correo verificada de sarenetes - Página principal

Documentación Comunicación Bibliotecas Sistemas y Tecnologías de

TÍTULO

Acceso abierto a las publicaciones cientificas: definición, recursos, copyright e impacto

R Melero

El profesional de la información 15 (4), 255-66

Conceptos de web 2.0 y biblioteca 2.0 : origen, definiciones y retos para las bibliotecas actuales

D Margaix-Arnal

El profesional de la información

El factor de impacto de las revistas cientificas: limitaciones e indicadores alternativos

R Aleixandre-Benavent, JC Valderrama-Zurián, G González-Alca

El profesional de la información

Prensa en internet: nuevos modelos de negocio en el escenario de la convergencia A Casero Ripollés

El profesional de la información 19 (6). 595-601

Google Scholar como herramienta para la evaluación científica.

D Torres-Salinas, R Ruiz-Pérez, E Delgado-López-Cózar

El profesional de la información 18 (5), 501-510

ANALITICA VISUAL EN E-LEARNING

DA Gómez-Aguilar, FJ García-Peñalvo, R Therón

El profesional de la información 23 (3)

Cibermedios y web 2.0: modelo de análisis y resultados de aplicación

R Rodriguez Martínez, L Codina, R Pedraza Jiménez

El profesional de la información 19 (1), 35-44

Arquitectura de la información y usabilidad en la web

R Baeza-Yates, C Rivera-Loaiza, J Velasco-Martín
CITADO POR AÑO

$206 \quad 2005$

$191 \quad 2007$

$\begin{array}{lr}\text { Citas } & 15851 \\ \text { Indice h } & 49 \\ \text { indice ito } & 408\end{array}$

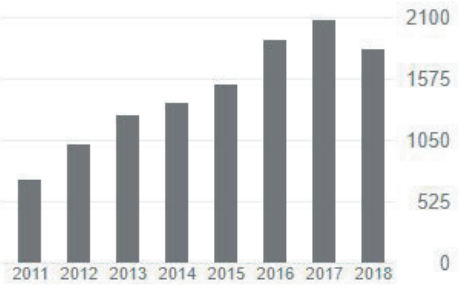

\begin{tabular}{l|l|l}
$188 \quad 2007$ & Coautores
\end{tabular}

$140 \quad 2010$

$132 \quad 2009$

$115 \quad 2014$

2014

$114 \quad 2010$

$110 \quad 2004$
Professor of Information Science.

Daniel Torres-Salinas

Universidad de Granada- Unida

7. Emilio Delgado López-Cózar Emilio Delgado López-Cózar
Professor Research Methods, Fa... JAVIER GUALLAR Professor of Library and Informat... >

(a) Tomàs Baiget "El profesional de la informacion".

Félix de Moya Anegón SClmago Research Group - SPAIN >

Fernanda Peset

$>$ 